\title{
ORTHODOX VENTRILOOUISM IN THE PSEUDO-EPHREMIC SERMON ON PALM SUNDAY
}

\author{
Phil J. Botha
}

University of Pretoria

\section{ABSTRACT}

One important objection against accepting the authenticity of the Syriac Sermon on Palm Sunday as being from the hand of Ephrem the Syrian, is the use of explicit Trinitarian language in lines 426-431 of the sermon. This section of text forms part of the unit that consists of lines 418-447 in which Israel is criticized for rejecting their 'King' in the desert (at Sinai), and the Jewish contemporaries of Jesus are criticized for rejecting 'the Son of the King' in Jerusalem. A close reading of these lines suggests that the part where the Holy Spirit and the Trinity are mentioned might constitute a later, 'more orthodox' interpolation into the original text. These lines disturb the original parallel and clash with the poetic quality of the original. The article considers the possibility that the sermon, without this interpolation, might after all have been written by Ephrem himself.

Keywords: Ephrem the Syrian, Sermon on Palm Sunday, orthodox expansions, trinity

\section{INTRODUCTION}

This article constitutes an investigation of lines 418-447 of the third of four metrical homilies (memre) published by Dom Edmund Beck under the name of Ephrem the Syrian (c.306-73) as Sermones II. ${ }^{1}$ According to the headings of the manuscripts Beck used to prepare the text, they are purportedly all from the hand of Ephrem, but serious doubt exists about their authenticity. Beck would agree that only the first one and a small part of the fourth one could probably have been written by Ephrem. He has serious

$1 \quad$ Edmund Beck, ed., Des heiligen Ephraem des Syrers Sermones II (Text and Translation) (2 vols.; CSCO 311-312, Scriptores Syri 134-135; Louvain: Secrétariat du CorpusSCO, 1970). 
doubts about especially the second one. ${ }^{2}$ Concerning the authorship of the third homily, which is under discussion here, Beck is also in doubt whether Ephrem could have written it for a number of reasons:

1. It is represented only by very late manuscripts; ${ }^{3}$

2. it is obvious that it has grown over time; ${ }^{4}$

3. it contains two loanwords from Greek not found elsewhere in Ephrem's genuine works; ${ }^{5}$ and

4. the precise dogmatic expression 'eternal Trinity' ${ }^{6}$ is used in this sermon, a formula which would point to a time later than that of Ephrem. ${ }^{7}$

2 See Beck, Sermones II (Translation), v-xii.

3 From the period 1000-1200 C.E., cf. Beck, Sermones II (Translation), ix. This should be compared to the dates of the oldest Ephremic manuscripts, dating from the year 517 (B.L. add. 14571) and 521 (Vat. Sir. 111). Cf. Christian Lange, The Portrayal of Christ in the Syriac Commentary on the Diatessaron (CSCO 616 Subsidia 118; Louvain: Peeters, 2005), 29.

4 Especially in its conclusion which has been expanded by seemingly endless repetitions. When these repetitions are considered, there can be little doubt that the homily has been expanded and therefore is no longer pristine.

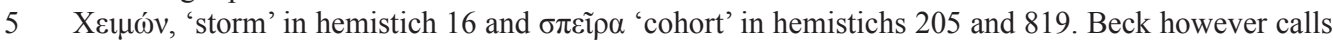
this 'eine Kleinigkeit,' thus a small matter. See Beck, Sermones II (Translation), ix.

6 The author refers to the Father, the Son and the 'Lord's Spirit' in the same context and then to all three

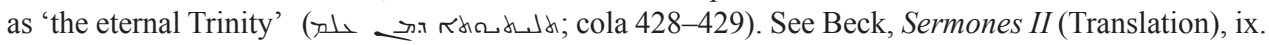

7 Such Trinitarian language in a Syriac sermon before the First Council of Constantinople in 381 seems improbable. The roots of a Trinitarian theology can be found in the New Testament, but the doctrine came into full bloom only through the work of Athanasius in the last decades of his life (293-373 C.E.) and through the influence of the Cappadocian Fathers (Basil of Caesarea, Gregory of Nyssa and Gregory of Nazianzus) at the end of the fourth century. See in this regard John N. D. Kelly, Early Christian Doctrines ( $5^{\text {th }}$ rev. ed.; London: Adam \& Charles Black, 1980), 263-269. In Hymni de Fide 73.21, the 'real' Ephrem (in one of his later works, written in Edessa and not in Nisibis (cf. Christian Lange, The Portrayal of Christ, 119) implies that the Father, Son and Holy Spirit are three, but also

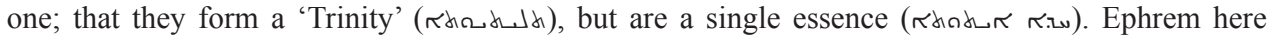
uses the analogy of the sun, its light, and its warmth which constitute three elements of one essence to describe the paradox of the divine triunity (see also his Hymni de Fide 40:1-2, 4). It is the lack of a clear and fixed metaphysical vocabulary in this and other instances which, according to Lewis Ayres, marks Ephrem's approach as 'pro-Nicene.' This indicates a familiarity with the controversies that followed after Nicaea. For an in-depth discussion of the development of Trinitarian theology in the fourth century and Ephrem's role in it, see Lewis Ayres, Nicaea and its Legacy: An Approach to Fourth-Century Trinitarian Theology (Oxford: Oxford University Press, 2004), 133-267. On the place of Ephrem the Syrian in this development, see pages 229-236, especially 234-235. The exposition of Ephrem almost seems to echo elements of the creed of Nicaea as it was translated into Syriac at the synod of Seleucia-Ctesiphon in 410 (cf. Lange, The Portrayal of Christ, 149). Lange, Portrayal of Christ, 147, has suggested that Ephrem probably was acquainted with the creed of Nicaea and informed about the schism which occurred in Antioch between the 'old-nicaean' and 'neo-nicaean' factions a decade or so before his death. For the text of Hymni de Fide, see Edmund Beck, ed., Des heiligen Ephraem des Syrers Hymnen de Fide (CSCO 154, Scriptores Syri 73; Louvain: Durbecq, 1955). 
In favour of Ephrem's name being connected to this sermon, Beck mentions the presence of familiar expressions and thoughts known from the 'genuine' works of Ephrem. ${ }^{8}$ What finally convinces him that the composition was not made by Ephrem, are clashes he perceives between statements in the sermon and Ephrem's genuine hymns. So, for instance, it is stated in hemistich 820 of the sermon that Zion did not rouse herself from sleep when Jesus entered Jerusalem on Palm Sunday, while in De Nativitate 6.23 Ephrem notes that the donkey woke her up and she then rose to kill the Lord. A second clash, in Beck's view, is that Ephrem elsewhere twice refers to the Aramaeans who were present when Jesus rode into Jerusalem (making use of the Vetus Syra rendering at John 12:20). This conviction, expressed in Ephrem's works De Virginitate 20.9 and Sermo de Fide 6.139-140, is absent from this sermon on Palm Sunday. ${ }^{9}$

Regarding the first of these two objections, I do not find a disturbing clash between the two contexts: In De Nativitate 6.23 it is the donkey who treads on (daughter) Zion and hurts her. Ephrem then uses irony to form a contrast between the sleeping Zion who wakes up to kill the 'Watcher,' as Jesus is called here. What is more, Christian Lange has recently pointed out that it is problematic to decide on the authenticity of a work on the basis of such clashes alone. ${ }^{10} \mathrm{~A}$ factor that would support the tradition that Ephrem composed the homily is its strong anti-Jewish polemical tone. ${ }^{11}$

8 So, for instance, the way in which the author uses the words $\kappa$ hał $\kappa$ and $\tau \downarrow \leftarrow \kappa$. See Beck, Sermones II (Translation), 74 n. 3.

9 Cf. Edmund Beck, ed., Des heiligen Ephraem des Syrers Hymnen de Nativitate (Epiphania). Text (CSCO 186, Scriptores Syri 82, Louvain: Secrétariat du CorpusSCO, 1959), 55. The second remark is an argumentum e silentio. There are also conspicuous similarities with works by Ephrem or closely associated with him. The author of the sermon (for instance) places considerable emphasis on the role of children who welcomed Jesus when he entered Jerusalem (in the sermon itself, the children are mentioned 13 times, but their presence is emphasized an absurd 23 times in the extrapolated conclusion). The purpose of this probably was to facilitate a connection with Ps. 8:3 ('out of the mouth of babies and infants, you have established strength because of your foes, to still the enemy and the avenger'). The author refers to this psalm text in hemistichs 188-189, saying 'And David would stir up the children and infants to praise,' using riljn as in Ps. 8:3. Beck, Sermones II (Translation), 77 n. 8 rightly notes that the children are not mentioned in Matthew's description of the entrance into Jerusalem, but later in Matt. 21:15 where the Peshitta also uses r.ll;. In the Commentary on the Diatessaron, the role of the children on Palm Sunday is also highlighted. The author of this work points out the symmetry of children playing a role both at Jesus' birth and at his death. Cf. Ephrem, Commentarii in Diatessaron 18.2. The translation of Christian Lange, Ephraem der Syrer: Kommentar zum Diatessaron II: Übersetzt und eingeleitet von Christian Lange (Fontes Christiani 54/2; Turnhout: Brepols, 2008), 504-505 was used.

10 Lange, The Portrayal of Christ, 9-11, notes that contradictions in exegetical ideas and images cannot stand on their own, since they can be attributed to different emphases in separate works; the lack of systematic exposition in Ephrem's poetical works; and the possibility of theological development in Ephrem.

11 Christine Shepardson describes the anti-Jewish polemics in this sermon as 'acerbic,' yet it does not come close to the harsh language Ephrem uses in his hymn De Azymis 19. For the latter, Shepardson uses the (arguably) stronger description 'vitriolic.' Cf. Christine Shepardson, Anti-Judaism and Christian Orthodoxy: Ephrem's Hymns in Fourth-Century Syria (NAPS Patristic Monograph Series 
This article, however, does not intend to prove or disprove that Ephrem composed the homily. It is a much more modest attempt to analyse the section of the text where mention is made of the 'eternal Trinity.' I intend to argue that a poetic and structural analysis of the immediate context of this pronouncement suggests that the reference to the Trinity must be regarded as a later interpolation. ${ }^{12}$ Someone other than the author, at a time when the Trinitarian issue had been resolved, thus felt that the homily should use Trinitarian language and consequently inserted some lines of poetry to render it 'more orthodox.' This is what the title of this article plays on when it speaks of 'orthodox ventriloquism.' If this hypothesis is correct, it would still not prove that Ephrem was the author of the homily, although the poetic style and arguments of this section of text do suggest proximity to the work of Ephrem. The connections between this segment of text and the rest of the homily, and the connections of it with the 'genuine' works of Ephrem, will consequently also be touched upon very briefly.

\section{POETIC ANALYSIS AND DISCUSSION OF LINES 418- 447: THE JEWS' HUMILIATION OF THE FATHER AND THE SON}

The liturgical homily on Palm Sunday ${ }^{13}$ comprises 895 cola with the following subsections: ${ }^{14}$

- Invitation to the feast (1-22);

- prayer for the worthy celebration of the feast by all creatures (23-122);

- this feast implies the rejection of the synagogue and the election of the Church (123-77);

- the prophetic predictions about the feast (178-321);

20; Washington: The Catholic University of America Press, 2008), 13 n. 38 (for the remark on the sermon under discussion here) and 34 (for the description of De Azymis 19). Shepardson argues (rightly) in her book that Ephrem's polemics against the Jews must be seen as an attempt to limit the influence of subordinationist Christians by suggesting that the 'Arians' are like the Jews who reject the divinity of Christ. See Shepardson, Anti-Judaism and Christian Orthodoxy, 4-9; for anti-Judaism as Christian polemics, see Elena Narinskaya, Ephrem, a 'Jewish'Sage: A Comparison of the Exegetical Writings of St. Ephrem the Syrian and Jewish Traditions (Studia Traditionis Theologiae 7; Turnhout: Brepols, 2010), 24.

12 Such later interpolations were indeed made, it is claimed, into the Commentary on the Diatessaron and even into metrical songs by Ephrem. Cf. Lange, The Portrayal of Christ, 29; and Andrew Palmer, 'Words, Silences, and the Silent Word: Acrostics and Empty Columns in Saint Ephraem's "Hymns on Faith,"' Parole de l'Orient 20 (1995): 129-200.

13 The Syriac title describes it as 'By the Holy Mar Ephrem, a memra on the Holy Festival of Palm Branches or Hosannas.' Beck remarks that it is the only example we have of a liturgical festival homily ascribed to Ephrem. Cf. Edmund Beck, ed., Sermones II (Text), vii.

14 The macrostructure as it is described by Beck in his translation of the homily, cf. Beck, Sermones II (Translation), 72-97. The Appendix, as it is found in MS Chicago Syriac A 12008 (Ch), is not included. 
- the synagogue rejected the entering King and was rejected (322-417);

- the synagogue rejected the Father and Son and chose idols and a robber respectively in their place (418-47);

- the final rejection of the synagogue, despite the fact that the Jews still hope (448$505)$;

- polemics against the Jews who think that the Messiah is yet to come (506-631);

- the Church as the New Jerusalem (632-717);

- conclusion: Repetition of the call to celebration and particulars from the feast (718895).

The section under investigation here (418-447) is described by Beck as 'The Synagogue Rejected the Trinity and Chose Idols.' It is my contention, however, that the reference to the Trinity represents an interpolation and that the section should be described as 'The Synagogue rejected the King in the desert and the King's Son in Jerusalem.' The whole segment is demarcated as a unit by two rhetorical questions: Immediately before its beginning in line 418 , there is a rhetorical question about what transgression the daughter of Jacob committed to receive such a harsh punishment; the unit itself also ends with a rhetorical question in cola 446-447 expressing the paradox of the Jews' harsh treatment of Christ.

As is typical of the work of Ephrem, there is a high density of poetic devices in these lines of poetry: parallels, antitheses, repetition, wordplay, hendiadys, allusion, irony, and paradox formulated with the help of a rhetorical question. In four of these cola, however, there are seemingly fewer poetic devices. They are the ones containing the reference to the Trinity, and this could serve as an indication that these lines form an interpolation into the original text. The probable interpolation is found in lines 426-431 where the 'Spirit of the Lord' is mentioned in addition to the Father and the Son about whom the rest of the section speaks, and Israel's disgraceful treatment of the 'eternal Trinity' is then mentioned in the form of a summary.

The text in this section basically describes how Israel treated God, the Father, with contempt in the wilderness, exchanging him for idols, and how the Son received the same treatment from the Jews in Jerusalem where a robber was preferred above him. There is thus a continuing parallel between the Father and the Son who are mentioned in lines 418 and 420-421 (as the 'King' and the 'King's Son'); 422 and 424 (as the 'Father' and the 'Son'); and 433 and 435 (the 'Word of the Father' and the 'Holy Son'). After that, the second person of the Trinity is again referred to as 'the Lord of Heaven' (line 437); the 'Heavenly One' (line 439); the 'Messiah' (line 441); 'He on whose nod the earth depends' (line 444); and 'our Saviour' (line 447). The Holy Spirit is not mentioned again in this section of text.

The mention of the Holy Spirit and the Trinity in lines 426-429 therefore interrupts the parallel portrayal of Israel as a shameless and licentious lover who disgraced the 'King' in the desert and the Jews of New Testament times who rejected the 'King's Son' 
when he entered into Jerusalem. Biblical Israel exchanged the 'King' for a calf as well as various images; the 'King's Son' was exchanged for a murdering robber in the time of the New Testament. Israel, referred to as 'she,' also caused the 'Word of the Father' and the 'Lord of Heaven' and the 'Heavenly One' to suffer dishonour and it is she who scoffed at the 'Holy Son' and persecuted the 'Messiah' and ill-treated him in her streets.

Lines 432-433, 434-435, 436-437, 438-439, and 440-441 could be taken as five sets of antithetic parallels which continue the argument of 'unjust substitution' left off in lines 422-425. The conclusion of these antithetic parallels is found in lines 442-443 forming an antithetic parallel to lines 444-445. It emphasizes the irony of the most obscure and impure creatures, bats, being worshipped in the holiest part of the temple ('her inner-chamber'), while the Creator who still holds everything in control, was illtreated in the profane domain of 'her streets.'

It is also significant that the second person address of Israel, 'you,' in line 418 is followed by three passive forms with either the 'Father' or the 'Son' as subject (lines 420-425). These passives all serve as examples of what the 'insulting' Israel is accused of in line 418. The passive forms are continued in lines 432-445, but they now have either an idol (or idols) or an epithet of the Son as subjects. Lines 426-431, however, interrupt this progression. The subjects of the verb is changed to a third person plural 'they' in line 426 and a third person feminine singular in lines 429 and 430. This could imply that lines 426-431 constitute an ill-fitting interpolation into the whole segment of text. In the rhetorical question which concludes this section, the audience is directly addressed and a third person feminine form is thus used to refer to Israel and the Jews.

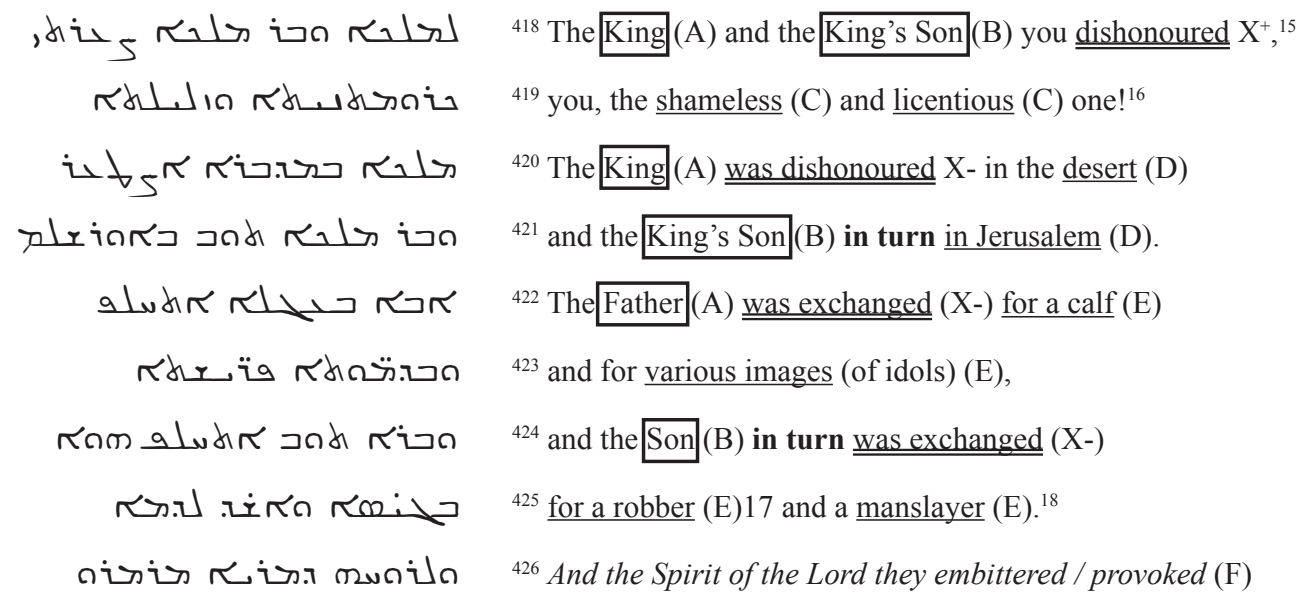

15 The word used in Luke 20:11 to describe what the second servant sent by the owner of a vineyard suffered.

16 These epithets probably constitute hendiadys for 'prostitute.'

17 Beck, Sermones II (Translation), 84 n. 2 remarks that this is the word used in John 18:40.

18 This double description probably also constitutes hendiadys, but it is necessary to balance 'calf' and 'images.' 


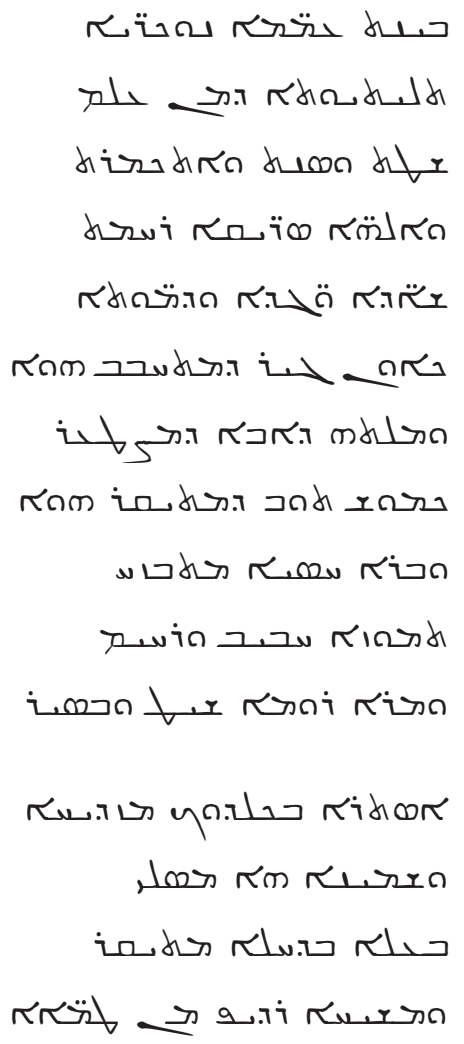

${ }^{427}$ among the foreign peoples. ${ }^{19}$

${ }^{428}$ The Eternal Trinity

${ }^{429}$ she treated with contempt $(\mathrm{F})$ and hated $(\mathrm{F})$ and saddened $(\mathrm{F}){ }^{20}$

${ }^{430}$ And worthless ${ }^{21}$ idols $(\mathrm{G})$ she loved $(\mathrm{H}+)$,

${ }^{431}$ demons and (gods of) fortune (G), ${ }^{22}$ and images (of idols) (G).

${ }^{432}$ For it is Kewon ${ }^{23}(\mathrm{G})$ who enjoyed love $(\mathrm{H}+),{ }^{24}$

${ }^{433}$ and the Word of the Father (B) who suffered dishonour (H-).

${ }^{434}$ Furthermore, it is $\underline{\mathrm{Chemosh}}^{25}(\mathrm{G})$ who was honoured $(\mathrm{H}+)$

${ }^{435}$ and the pure Son (B) was scoffed at (H-).

${ }^{436} \mathrm{Tammuz}^{26}(\mathrm{G})$ was (considered) cherished $(\mathrm{H}+)$ and loved $(\mathrm{H}+)$

${ }^{437}$ and the Lord of heaven (B) (was considered) worthless (H-) and despicable (H-).

${ }^{438}$ Astarte $^{27}(\mathrm{G})$ was solemnly carried around $(\mathrm{H}+)$ everywhere,

${ }^{439}$ and the heavenly One (B) spurned (H-).

${ }^{440}$ Baal (G) was worshipped full of fear $(\mathrm{H}+)$,

${ }^{441}$ and the Messiah (B) was persecuted by the unclean ones (H-).

19 Note the word-play. The expression 'to embitter his Spirit' is taken from Isa. 63:10. See also Ps. 106:33; and the idea of worshipping the idols of the heathen in Ps. 106:35-36.

20 Compare this to Isa. 63:10 and Eph. 4:30 - in Isa. 63:10 it is said that 'they rebelled, they grieved his Holy Spirit.' In the Hymni De Resurrectione 3.2, Ephrem similarly remarks that Israel 'loved'

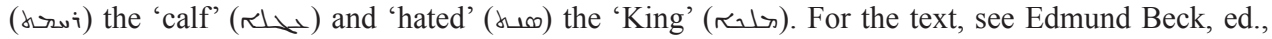
Des Heiligen Ephraem des Syrers Paschahymnen (De azymis, de crucifixione, de resurrectione) (CSCO 248, Scriptores Syri 108; Louvain: Secrétariat du CorpusSCO, 1964), 85.

21 Passive participle pe'al.

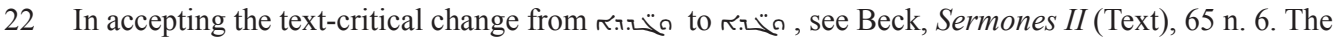
word is used in a comparable context also in Ephrem's Sermones II, Sermon 1, line 1750. See Beck, Sermones II (Translation), 84, n. 4.

23 Beck, Sermones II (Translation), 84 n. 5 says that this refers to Saturn, also mentioned in Contra Haereses 8:15.

24 The Ethpa'al of wa to 'be beloved, cherished, embraced.'

25 The principal Moabite god mentioned in 1 Kings 11:7.

26 Tammuz is the name of a deity mentioned only in Ezek 8:14. He seems to have been a Sumerian and later a Babylonian vegetation deity. His name was consequently given to the fourth Babylonian month. Cf. '교, HALOT 4: 125 (entry 10194).

27 Or Asherah, the Ugaritic consort of El. She is mentioned in association with Baal, the well-known fertility god of Canaan, in Judges 6:25. 


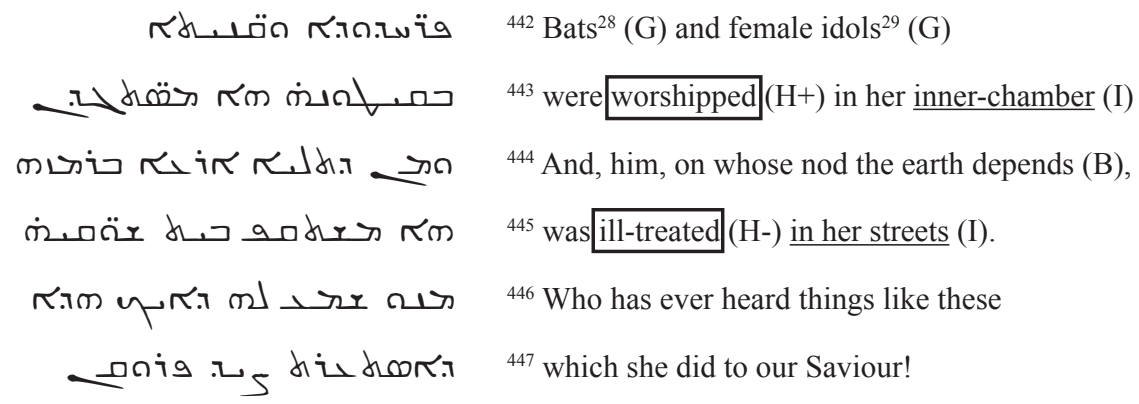

In line 418, the parallel pair 'the King' and 'the King's Son' is introduced, who are said to have been dishonoured by the 'shameless and licentious' second person feminine singular addressee (this description probably constitutes hendiadys). The theme which was thus announced is then expanded by explaining how 'the King' was dishonoured in the desert and 'the King's Son' in Jerusalem, so that a parallel is formed between the two subjects, the two prepositions, and the two locations of the dishonouring. The verb is not repeated (ellipsis), but is represented by the particle snł. Since this particle is repeated in line 424 (the second time it does not constitute ellipsis), a parallel is constituted between the parallels in lines 420-421 and 422-425. This particle is once more used in line 434, establishing a connection between the idols which are mentioned in line 423 and those that are mentioned in lines 432-443. In the parallel formed by lines 422-423 with lines 424-425 (which actually explains the parallel in lines 420-421, which in turn explains the parallel in line 418), the verb ('was exchanged') is repeated. To form a parallel with 'a calf and various images' in lines 422-423, the author again employs hendiadys (a robber and a manslayer $=$ murderous robber) to refer to Barabbas. This serves to balance the noun-pair 'calf' and 'idols' in 422-423.

The 'images' mentioned in line 423 are again taken up in line 431, but this would seem like a disturbing doublet. The same applies to the repetition of 'she loved' in 430 and 'enjoyed love' in 432 (note also 'loved' in 436). The idea of 'love' for the idols is

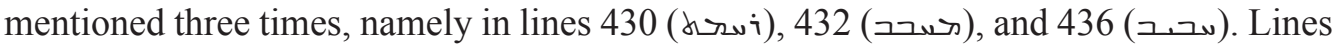
434-445 could be understood as an explication of the theme announced in lines 418-25, namely the substitution of the Father and Son for idols. It would thus seem that the interpolation begins at line 426 and ends at line 431.

Where lines 418-425 made extensive use of parallelism, lines 432-445 are constructed around antitheses: 'Kewon' forms an antithesis to the 'Word of the Father'; 'Chemosh' to 'the pure (or holy) Son'; 'Tamuz' to the 'Lord of Heaven'; 'Astarte' to 'the

28 Beck, Sermones II (Translation), 85 n. 1 remarks that the Syriac word refers to vespertilio (a bat) or noctua (a night-owl), and that this word occurs in Is $2: 20$, but that it is used here in a metaphorical sense.

29 Beck, Sermones II (Translation), 85 n. 2 remarks that the MSS, with the exception of Y, have qnâyatâ; MS Y has genyâtâ which is used in 1 Sam 7:3 to refer to the Ashtarot in conjunction with other 'foreign gods.' 
Heavenly One'; 'Baal' to 'the Messiah'; and 'bats and female idols' to 'him on whose nod the earth depends.' The connections between the antithetic pairs are strengthened through the repetition of $\mathrm{K} n \mathrm{~m}$ in lines 432 and 434; the preposition $د$ in lines 438 and 440, and the suffix 3 feminine singular in lines 443 and 445. It is also strengthened by the use of alliteration in the names Kewon and Chemosh at the beginning of lines

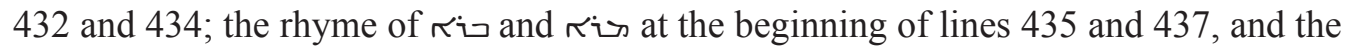
alliteration of 3 and ar the beginning of lines 439 and 441 . The section of text ends with a rhetorical question expressing a paradox, something of which Ephrem was very fond.

In contradistinction to the beginning and end of this segment of the homily which are so densely packed with poetic devices, the contested lines have fewer poetic characteristics. Not only do they interrupt the parallel formed by the Father and the Son, but the only significant poetic characteristic in these lines is the use of alliteration in line

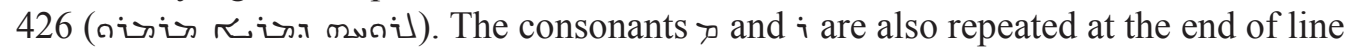
429. What is more disturbing, however, is the fact that the dual parallel structure had to be extended to create a tripartite parallelism:

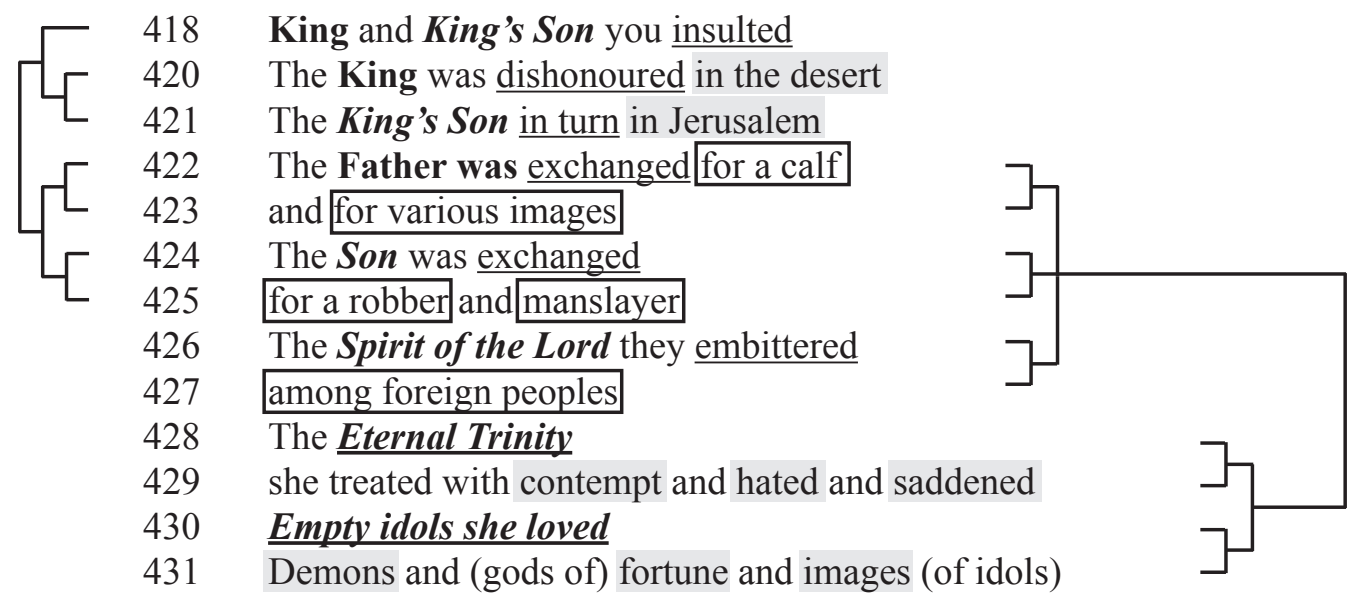

The lines on the left represent the structural combination of cola in the original composition and those on the right represent the structure with the Trinitarian interpolation in 426-431. It can be seen from this that the two structures clash. The parallel of the locations 'in the desert' and 'in Jerusalem' now had to be extended to 'among the foreign peoples.' This newly created parallelism is less successful, since 'among the peoples' does not refer to a particular location and incident as the other two do. The verb 'dishonoured' in line 420 (which could be represented in the parallel line 421 with 'in turn') as well as the verb 'exchanged,' which is repeated in the parallelism of lines 422 and 424, had to be augmented by the less successful parallel 'embittered' in line 426. The tripartite description 'treated with contempt,' 'hated,' and 'saddened,' 
which now summarizes the 'substitution' of Father and Son in the wilderness and in Jerusalem and the abuse of the Holy Spirit in the Promised Land also does not fit properly. The 'images' of idols mentioned in line 423 was extended to create an 'unholy trinity' of 'demons and gods of fortune and images of idols' in line $431,{ }^{30}$ which would now form a parallel with lines 428-429. It is conceivable that the original composition did have the variation of 'King' and 'King's Son' in lines 418-421 which was developed into 'Father' and 'Son' in lines 422-425 and that this mention of two persons from the Trinity gave the cue for the extension with the 'Spirit of the Lord' and the summary statement about the Trinity. It thus seems probable that lines 426-431 were inserted later, irrespective of who the author of the homily might originally have been. If lines 426-431 are removed, the continuity of 418-425 with $432-447$ is restored: Note the semantic field of $i_{5}$, 'insulted' (418); i $\downarrow_{5} \kappa$, 'was dishonoured' (420); i $\downarrow_{5} \rightarrow$, 'suffer

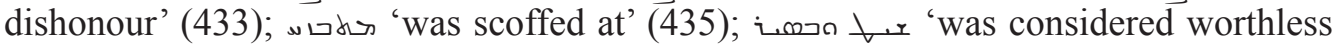
and despicable' (437); and, spurned' (439).

\section{THE RELATIONSHIP OF THIS SECTION OF THE TEXT WITH THE REST OF THE HOMILY AND WITH THE GENUINE WORKS OF EPHREM}

It would seem that the section of text under investigation here (418-47) fits well into the homily as a whole. God the Father is mentioned twice in this section, and another nine times in the homily as a whole. ${ }^{31}$ Christ is referred to as the 'Son' or the 'King's Son' in this section four times, and elsewhere another fifteen times. ${ }^{32}$ Especially the title 'King's Son,' a title which is also used in lines 18, 101, and 782, and the consistent reference to Christ as the 'King' who has come to Zion on Palm Sunday, confirm the integrity of these lines with the rest of the homily. In the rest of the homily, however, there is no other similar reference to the 'Spirit of the Lord' except for the reference to the 'dew of the Spirit of the seers' in line 147, 33 the quotation from Proverbs 30:4 where reference is made to 'him who binds the Spirit in the hollow of his hands' in line $254,{ }^{34}$ and a Trinitarian formula at the end of the sermon where it says in lines 890-891, 'Praise him and his Father, who sent him, and the Spirit who fulfils and completes!' 35

30 The use of three synonymous verbs also constitutes emphasis, but in this case the synonyms seem to have been chosen to fit the three Persons of the Trinity. It is possible that the author had a context such as Deut. 32:16-17 and 21 in mind where it is described how Israel provoked God to anger by worshipping strange gods and demons (see line $431 \mathrm{also}$ ). The expression to 'grieve' or 'embitter' the Holy Spirit is known from Isa. 63:10, Ps. 106:33, and Eph. 4:30. Cf. also Ps. 78:40.

31 In cola $267,298,340,523,695,703,747,787$, and 890 .

32 In cola 18, 94, 101, 162, 255, 334, 345, 524, 695, 729, 783, 789, 792, 804, and 831.

33 In following Beck's proposal to change runin to runi., see Beck, Sermones II (Text), 58 n. 22.

34 Beck notes that Ephrem also quotes this verse more completely in the hymns De Fide 10.14-5. Cf. Beck, Sermones II (Translation), 79 n. 10.

35 MS Chicago has an alternative reading which includes mention of the 'Holy Spirit.' Cf. Beck, Sermones II (Text), 77 n. 1. 
Beck mentions the almost endless repetitions and the introduction of new thoughts in the conclusion of the homily. ${ }^{36}$ This makes it difficult to judge whether this concluding formula originally formed part of the sermon. It would therefore be better to leave it out of consideration and to consider explicit Trinitarian formulae as later attempts to display orthodox doctrine.

It is perhaps noteworthy that the story which Ephrem most frequently uses to argue that the Jews have been rejected and the Gentiles elected, is the story about the golden calf in Exodus $32 .{ }^{37}$ The connection between idolatry and adultery which is made in this section of the homily is also a typical feature of the work of Ephrem. ${ }^{38} \mathrm{He}$ similarly refers to God as the 'King' who married his bride at Sinai ${ }^{39}$ and to Jesus as 'the Son of the King' ${ }^{40}$ and also makes the connection between biblical Israel who rejected God and New-Testament Jews who rejected Jesus. ${ }^{41}$

\section{CONCLUSION}

It would seem that this homily on Palm Sunday probably did not include lines 426-31 in its original form and that someone later added it to ascertain that Trinitarian language is used in the description of the Israelites' rejection of God at Sinai and the Jews' rejection of Christ in Jerusalem. These two instances of apostasy from God formed a parallel in the mind of the original author, but the parallel is now demolished through a lopsided reference to rebellion against the Holy Spirit. The addition would probably have served to satisfy doctrinal requirements from a time after the First Council of Constantinople in 381 C.E. If this supposition is correct, it would mean that the original composition could have been made during the life of Ephrem. The various similarities of this section of the homily with the genuine metrical compositions of Ephrem could then also be interpreted as an indication that the homily was composed by Ephrem the Syrian. The anti-Jewish polemical slant in the homily similarly points to a time of origin when the

36 Beck, Sermones II (Translation), ix.

37 Shepardson, Anti-Judaism and Christian Orthodoxy, 80. It should be noted, however, that this representation is repeatedly encountered in his poetic works, while his prose commentary on Exodus has a much more lenient treatment of this episode. See the Commentary on Exodus, especially Section 32.8 where he simply says that Moses broke the tablets since they were no use 'to a people who had replaced the One who laid down the law with a calf.' Cf. The the translation of Kathleen McVey, ed., St. Ephrem the Syrian, Selected Prose Works: Commentary on Genesis, Commentary on Exodus, Homily on our Lord, Letter to Publius (trans. E. G. Mathews and J. P. Amar; Washington: The Catholic University of America Press 1994), 264. See also Shepardson, Anti-Judaism and Christian Orthodoxy, 82 n. 42; and Elena Narinskaya, Ephrem, a 'Jewish'Sage, 51-55, who argues that Ephrem generally follows Jewish exegesis in his commentaries and that his hymns, which were (more specifically) directed to Christians, are much more critical.

38 Shepardson, Anti-Judaism and Christian Orthodoxy, 83 points out that Ephrem did not create this metaphor, but calls it 'inextricably linked' in the work of Ephrem.

39 De Resurrectione 3.2. Edmund Beck, ed., Des Heiligen Ephraem des Syrers Paschahymnen, 85.

40 De Resurrectione 3.3. Edmund Beck, ed., Des Heiligen Ephraem des Syrers Paschahymnen, 85.

41 De Crucifixione 3.3-5. Edmund Beck, ed., Des Heiligen Ephraem des Syrers Paschahymnen, 85. 
subordinationist ('anti-Arian') controversy, also addressed at Constantinople in 381, was still contentious.

\section{BIBLIOGRAPHY}

Ayres, Lewis. Nicaea and its Legacy: An Approach to Fourth-Century Trinitarian Theology. Oxford: Oxford University Press, 2004.

Beck, Edmund, ed. Des heiligen Ephraem des Syrers Carmina Nisibena II. Corpus Scriptorum Christianorum Orientalium 240, Scriptores Syri 102. Louvain: Secrétariat du CorpusSCO, 1963.

- Des heiligen Ephraem des Syrers Hymnen de Fide. Text. Corpus Scriptorum Christianorum Orientalium 154, Scriptores Syri 73. Louvain: Durbecq, 1955.

- Des heiligen Ephraem des Syrers Hymnen de Nativitate (Epiphania). Text. Corpus Scriptorum Christianorum Orientalium 186, Scriptores Syri 82. Louvain: Secrétariat du CorpusSCO, 1959.

- Des heiligen Ephraem des Syrers Hymnen de Virginitate. Corpus Scriptorum Christianorum Orientalium 223, Scriptores Syri 94. Louvain: Secrétariat du CorpusSCO, 1962.

-Des heiligen Ephraem des Syrers Paschahymnen (De azymis, de crucifixione, de resurrectione). Corpus Scriptorum Christianorum Orientalium 248, Scriptores Syri 108. Louvain: Secrétariat du CorpusSCO, 1964.

- Des heiligen Ephraem des Syrers Sermones II. Text. Corpus Scriptorum Christianorum Orientalium 311, Scriptores Syri 134. Louvain: Secrétariat du CorpusSCO, 1970.

- Des heiligen Ephraem des Syrers Sermones II. Translation. Corpus Scriptorum Christianorum Orientalium 312, Scriptores Syri 135. Louvain: Secrétariat du CorpusSCO, 1970.

-Des heiligen Ephraem des Syrers Sermo de Domino Nostro. Corpus Scriptorum Christianorum Orientalium 270. Scriptores Syri 116. Louvain: Secrétariat du CorpusSCO, 1966.

Brock, Sebastian. The Luminous Eye: The Spiritual World Vision of Saint Ephrem the Syrian. Rev. ed. Cistercian Studies Series 124. Kalamazoo, Mich.: Cistercian Publications, 1992.

Ephraem der Syrer. Kommentar zum Diatessaron. Translated by Ch. Lange. 2 Vols. Fontes Christiani 54/1-2. Turnhout: Brepols, 2008.

Kelly, John N. D. Early Christian Doctrines. $5^{\text {th }}$ rev. ed. London: Adam \& Charles Black, 1980.

Koehler, Ludwig, Walter Baumgartner and Johann J. Stamm. The Hebrew and Aramaic Lexicon of the Old Testament. Translated and edited under the supervision of M. E. J. Richardson. 4 vols. 3d ed. Leiden: Brill, 1994-2000.

Lange, Christian. The Portrayal of Christ in the Syriac Commentary on the Diatessaron. Corpus Scriptorum Christianorum Orientalium 616, Subsidia 118. Louvain: Peeters, 2005.

McVey, Kathleen, ed. St. Ephrem the Syrian, Selected Prose Works. Translated by E. G. Mathews and J. P. Amar. Washington: The Catholic University of America Press, 1994.

Narinskaya, Elena. Ephrem, a 'Jewish'Sage: A Comparison of the Exegetical Writings of St. Ephrem the Syrian and Jewish Traditions. Studia Traditionis Theologiae: Explorations in Early and Medieval Theology 7. Turnhout: Brepols, 2010.

Palmer, Andrew. 'Words, Silences, and the Silent Word: Acrostics and Empty Columns in Saint Ephraem's "Hymns on Faith," Parole de l'Orient 20 (1995): 129-200. 
Shepardson, Christine. Anti-Judaism and Christian Orthodoxy: Ephrem's Hymns in Fourth-Century Syria. North American Patristic Society Patristic Monograph Series 20. Washington: The Catholic University of America Press, 2008. 